\title{
Effect of Mindfulness-Based Cognitive Therapy on Symptoms of Depression: A Systematic Review
}

\author{
Fakhrun Nisa' Fiddaroini, Ah. Yusuf*, Praba Diyan Rachmawati \\ Faculty Of Nursing, Airlangga University, Indonesia \\ *ah-yusuf@fkp.unair.ac.id
}

\begin{abstract}
Depression is a common mental health disorder. The main symptoms of depression are a lack of interest in the activities of daily life and suicidal thoughts. Mindfulness-based cognitive therapy (MBCT) is effective in preventing or reducing symptoms of depression. This study aimed to determine the effectiveness of mindfulness-based cognitive therapy in reducing symptoms of depression. This systematic review was based on Preferred Reporting Items for Systematic Reviews and Meta-Analyses (PRISMA). Five databases included in this study This systematic review uses 10 articles that fit the inclusion criteria outcome. The result showed mindfulness-based cognitive therapy intervention from the research was reviewed significantly and has been shown to be an effective psychological intervention for reducing depressive symptoms in various populations. Mindfulness-based cognitive therapy has better results for reducing depressive symptoms and has a positive impact on reducing mental health problems and can be used by nurses and other mental health practitioners.
\end{abstract}

Keywords : Depression; Mindfulness; Mindfulness-Based Cognitive Therapy

Received August 8, 2020; Revised August 20, 2020; Accepted August 26, 2020

(c) (7) (O) STRADA Jurnal Ilmiah Kesehatan, its website, and the articles published there in are licensed under a Creative Commons Attribution-ShareAlike 4.0 International License. 


\section{STRADA Jurnal Ilmiah Kesehatan}

DOI: $10.30994 /$ sjik.v9i2.383

ISSN: 2252-3847 (print); 2614-350X (online)

Vol.9 No.2 November 2020 Page.761-771

\section{BACKGROUND}

Adolescent risk problems are unhealthy diet, physical activity, injury, use of firearms, premarital sexual behavior, abuse of Narcotics, Psychotropics, and other addictive substances (Drugs), depression, suicide, and aggressive behavior (Krisnana et al., 2019; Papalia \& Feldman, 2008; Potter \& Perry, 2005; Santrock, J.W., 2007). Depression appears in late childhood and early adolescence (United Nations Children's Fund (UNICEF), 2011). Depression in adolescents is not only a feeling of stress but is a serious condition, affecting behavior, emotions and thinking, and becomes a permanent condition. If the stress phase is not resolved immediately, it can be a depressive phase, and lead to severe behavioral disorders and substance abuse (Howard et al., 2009; Ktut Dianovinina, 2018). Early detection and preventive interventions need to be done before the onset of depression, especially in early adolescents aged 10 and 14 years (United Nations Children's Fund (UNICEF), 2011).

World Health Organization in 2017, estimates about 322 million people live with depression in the world and nearly half are in the western pacific region and southeast Asia (WHO, 2017). WHO has identified depression as the prior cause of mental health disability and is projected to rank second as a cause of disability in 2020 (Stuart, 2016). WHO states that depression also occurs in children and adolescents age under 15 years, while the percentage is still lower than older age. The estimated number of people with depression increased by 18.4\% between 2005 and 2015 (Vos et al., 2017; WHO, 2017). The results of a survey by the Center for Disease Control (CDC) in America stated during 2009-2012, the incidence of depression in the 12-17-year-olds was 7.6\% (Pratt, L.A., \& Brody, D.J., 2014). Around $21.8 \%$ of people in Indonesia have moderate or severe depression, especially adolescents (Peltzer \& Pengpid, 2018). Medical intervention is the treatment choice for children with mental health disorders. However, it is necessary to identify non-pharmacological approaches as an adjunct therapy and complementary therapies were popular therapy for children and adolescents (Goldman et al., 2008). Mindfulness is one of the complementary therapies for mental health disorders problems. It is a current awareness of one's experiences, combined with acceptance and nonjudgmental attitude (Bishop et al., 2004; Kabat-Zinn, J., 2013). Mindfulness can be easy treatment as a specific form of meditation that seeks to improve psychological functioning through synergistic efforts between attention regulation, self-awareness, and emotional regulation, thereby increasing psychological resilience and self-regulation (Tang et al., 2015). Mindfulness-based cognitive therapy (MBCT) is a psychosocial group-based intervention consisting of training in mindfulness meditation and elements of cognitivebehavioral therapy (CBT).

The previous finding related to Mindfulness-Based Intervention (MBI) and mental health in adults has experienced the expansion of mindfulness interventions in adolescents (Weare \& Nind, 2011). Fung et al. in 2019 state that mindfulness interventions are beneficial for adolescents in reducing perceived stress, internalizing problems, and reducing mental health symptoms through improved emotional regulation (Fung et al., 2019). Therefore, this study aimed to examine changes in depressive symptoms for adolescents receiving mindfulness-based cognitive therapy and to further investigate whether there was the effectiveness of mindfulness-based cognitive therapy in reducing depressive symptoms. 


\section{STRADA Jurnal Ilmiah Kesehatan}

DOI: $10.30994 /$ sjik.v9i2.383

ISSN: 2252-3847 (print); 2614-350X (online)

Vol.9 No.2 November 2020 Page.761-771

\section{METHODS}

This Systematic Review used elements related to Preferred Reporting Items for Systematic Reviews and Meta-Analyzes (PRISMA) statements. Five databases were used including Scopus, Pubmed, Science Direct, Pro-Quest, and CINAHL with articles published from 2015 to 2020. Only full text and English articles were included in this study. The keywords used in the search for the article were "depression" AND "mindfulness" AND "mindfulness-based cognitive therapy". After several articles were found, the authors conducted an analysis and synthesis of the articles according to the specified inclusion and exclusion criteria. The inclusion criteria in this systematic review were (1) research discusses the effect of mindfulness-based cognitive therapy on depression (2) original research, and (3) the use of adolescent and adult research subjects. The exclusion criteria in this systematic review were (1) the results of the study did not explain the effect of mindfulness-based cognitive therapy on depression (2) the research from a thesis, dissertation, abstract, or part of a conference. The article search process was carried out in May-June 2020. The article search used keywords that had been determined by the compilers and provided limits on inclusion and exclusion criteria. The data collected and selected one by one by the compiler to determine the suitability of the desired articles and delete the duplicate articles. After obtaining the appropriate articles, the articles were analyzed one by one and grouped to get the results. The next step was to discuss based on the points obtained from the selection results.

\section{RESULT}

The initial literature search obtained 448 articles (102 from Scopus, 92 from PubMed, 114 from Science Direct, 93 from ProQuest, and 47 from CINAHL). After reviewing the abstracts for relevance and matching the inclusion criteria, 56 articles were selected for the full-text review. There were 46 full-text articles excluded for reasons not related to mindfulness-based cognitive therapy in reducing depressive symptoms. Finally, there were 10 articles selected for review, as listed in figure 1.

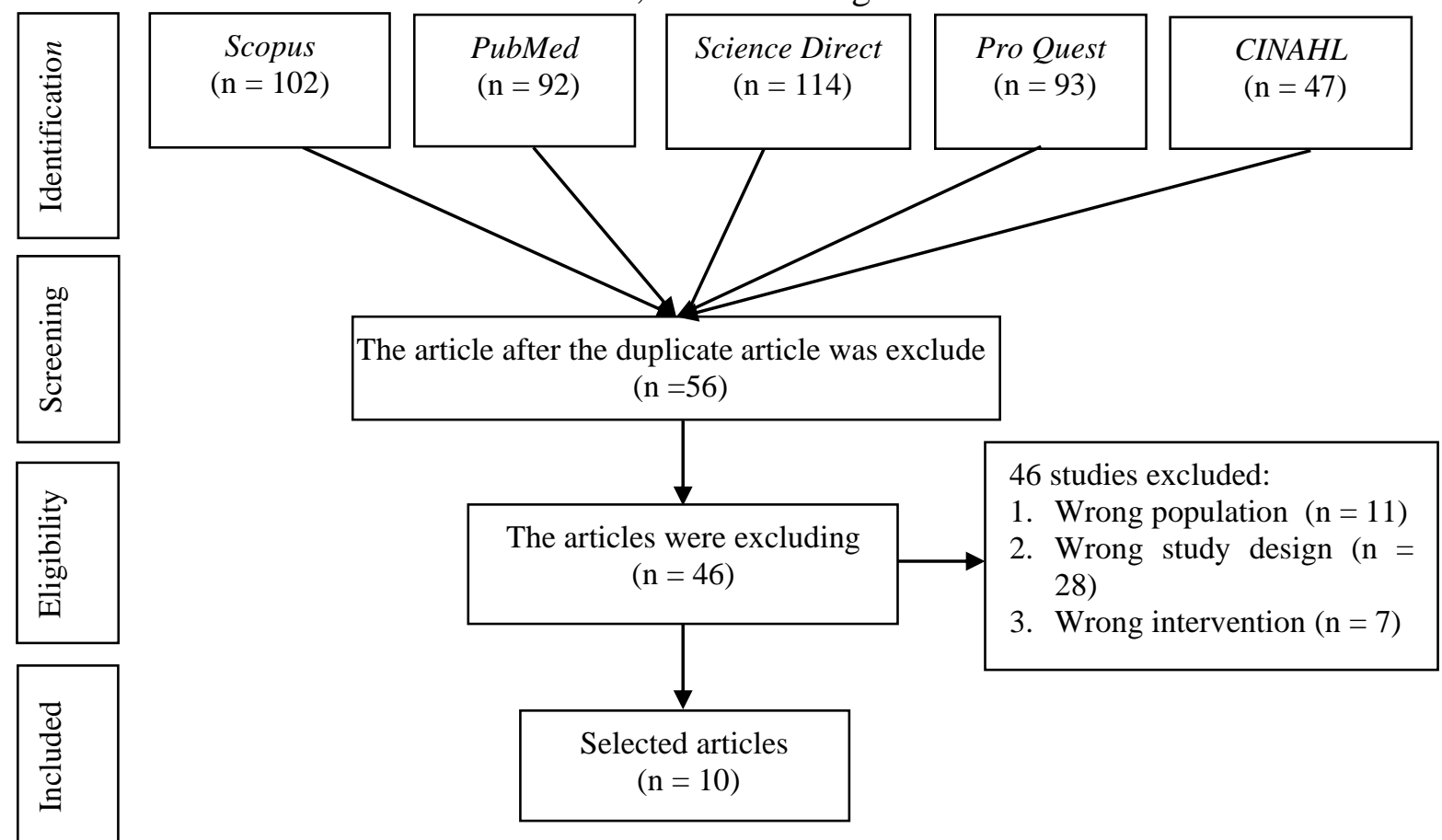

Figure 1. Flow chart of the study identification process 


\section{STRADA Jurnal Ilmiah Kesehatan}

DOI: $10.30994 /$ sjik.v9i2.383

ISSN: 2252-3847 (print); 2614-350X (online)

Vol.9 No.2 November 2020 Page.761-771

The analysis of the 10 articles was presented in table 1.

Table 1. Mindfulness-Based Cognitive Therapy for Depression Symptoms

\begin{tabular}{|c|c|}
\hline Research Title & Research methods \\
\hline $\begin{array}{l}\text { Effectiveness of } \\
\text { mindfulness-based } \\
\text { cognitive behavior therapy } \\
\text { on life satisfaction, and life } \\
\text { orientation of adolescents } \\
\text { with depression and } \\
\text { suicidal ideation (Raj et al., } \\
2019 \text { ) }\end{array}$ & $\begin{array}{l}\text { Design: Experimental study The results showed that } \\
\text { Sample: } 30 \text { participants mindfulness-based cognitive } \\
\text { Variables: Mindfulness- therapy intervention was an } \\
\text { based cognitive therapy, life effective intervention to } \\
\text { satisfaction, life orientation, improve the psychological } \\
\text { family functioning, function of depressed } \\
\text { depression, suicidal behavior adolescents with suicidal } \\
\text { Instrument: } \\
\text { The Modified Scale for } \\
\text { Suicidal Ideation (MSSI) } \\
\text { Beck's Depression Inventory } \\
\text { (BDI) } \\
\text { Satisfaction with Life Scale } \\
\text { Revised Life Orientation Test } \\
\text { (LOT-R) } \\
\text { Analysis: Analysis of } \\
\text { variance (ANOVA) }\end{array}$ \\
\hline
\end{tabular}

Effect of a Mindfulness- Design: Experimental study This study showed that Based Intervention Sample: 81 participants mindfulness-based cognitive Program on Variables: Mindfulness, therapy intervention can Comprehensive Mental Mental Health Problems provide a significant reduction Health Problems of Instrument: in somatization scores, Chinese Undergraduates The Symptoms Check List 90 obsessive-compulsive (Liu, 2019)

(SCL 90) symptoms, interpersonal The SCL90 was composed of sensitivity, depression, 90 items and nine subscales including phobia, paranoia, and Somatization, Depression, psychoticism.

Obsessive-Compulsive, Interpersonal Sensitivity, Hostility, Anxiety, Paranoid Ideation, Phobic Anxiety, and Psychoticism

Analysis: Analysis of variance (ANOVA)

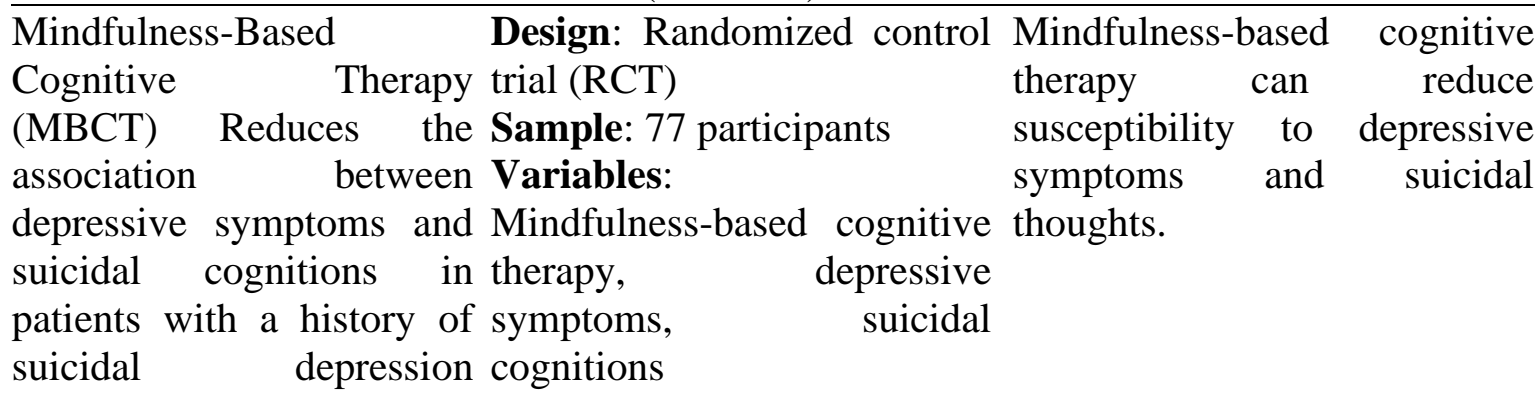
(Barnhofer et al., 2015) Instrument: 


\section{STRADA Jurnal Ilmiah Kesehatan}

DOI: $10.30994 /$ sjik.v9i2.383

ISSN: 2252-3847 (print); 2614-350X (online)

Vol.9 No.2 November 2020 Page.761-771

\begin{tabular}{|c|c|c|}
\hline Research Title & Research methods & Result \\
\hline & $\begin{array}{l}\text { Beck Depression Inventory-II } \\
\text { (Beck, Steer, \& } \\
\text { Brown, 1996) } \\
\text { Suicidal thinking, as assessed } \\
\text { through the Suicidal } \\
\text { Cognitions Scale (Rudd et al., } \\
\text { 2001). } \\
\text { Analysis: ANOVA }\end{array}$ & \\
\hline $\begin{array}{l}\text { Group and Individual } \\
\text { Mindfulness-Based } \\
\text { Cognitive } \\
\text { (MBCT) Are } r \text { Both } \\
\text { Effective: a Pilot } \\
\text { Randomized Controlled } \\
\text { Trial in Depressed People } \\
\text { with a Somatic Disease } \\
\text { (Schroevers et al., 2016) }\end{array}$ & $\begin{array}{l}\text { Design: Randomized control } \\
\text { trial (RCT) } \\
\text { Sample: } 56 \text { participants } \\
\text { Variables: } \\
\text { Mindfulness-based cognitive } \\
\text { therapy, depressed people } \\
\text { Instrument: } \\
\text { Beck Depression Inventory-II } \\
\text { (BDI-II) } \\
\text { General Anxiety Disorder } 7 \\
\text { (GAD-7) } \\
\text { Well-Being Index (WHO-5) } \\
\text { Five Facet Mindfulness } \\
\text { Questionnaire (FFMQ) } \\
\text { Self-Compassion Scale } \\
\text { Analysis: T-tests, chi- } \\
\text { squared tests, fisher's exact } \\
\text { test }\end{array}$ & $\begin{array}{l}\text { This study found that } \\
\text { mindfulness-based cognitive } \\
\text { therapy both as a group and } \\
\text { individually can improve } \\
\text { psychological well-being, } \\
\text { attention skills, and reduce } \\
\text { symptoms of depression. }\end{array}$ \\
\hline $\begin{array}{l}\text { Mindfulness-based } \\
\text { zognitive therapy for } \\
\text { patients with chronic, } \\
\text { treatment-resistant } \\
\text { depression: A pragmatic } \\
\text { tandomized controlled trial } \\
\text { (Alampay et al., 2020) }\end{array}$ & $\begin{array}{l}\text { Design: Randomized control } \\
\text { trial (RCT) } \\
\text { Sample: } 106 \text { participants } \\
\text { Variables: Mindfulness- } \\
\text { based cognitive therapy, } \\
\text { resistant-depression } \\
\text { Instrument: } \\
\text { Ruminative Response Scale } \\
\text { (RRS-EXT) } \\
\text { Quality of life was assessed } \\
\text { with the World Health } \\
\text { Organization Quality of Life } \\
\text { scale skills and self- } \\
\text { Mindfulness skess } \\
\text { compassion were assessed } \\
\text { with the Five Facet } \\
\text { Mindfulness Questionnaire } \\
\text { Self-Compassion Scale } \\
\text { Analysis: } \\
\text { analysis of covariance }\end{array}$ & $\begin{array}{lr}\text { Depressive } & \text { symptoms } \\
\text { decreased } & \text { significantly after } \\
\text { giving } & \text { mindfulness-based } \\
\text { cognitive therapy intervention. }\end{array}$ \\
\hline
\end{tabular}




\section{STRADA Jurnal Ilmiah Kesehatan}

DOI: $10.30994 /$ sjik.v9i2.383

ISSN: 2252-3847 (print); 2614-350X (online)

Vol.9 No.2 November 2020 Page.761-771

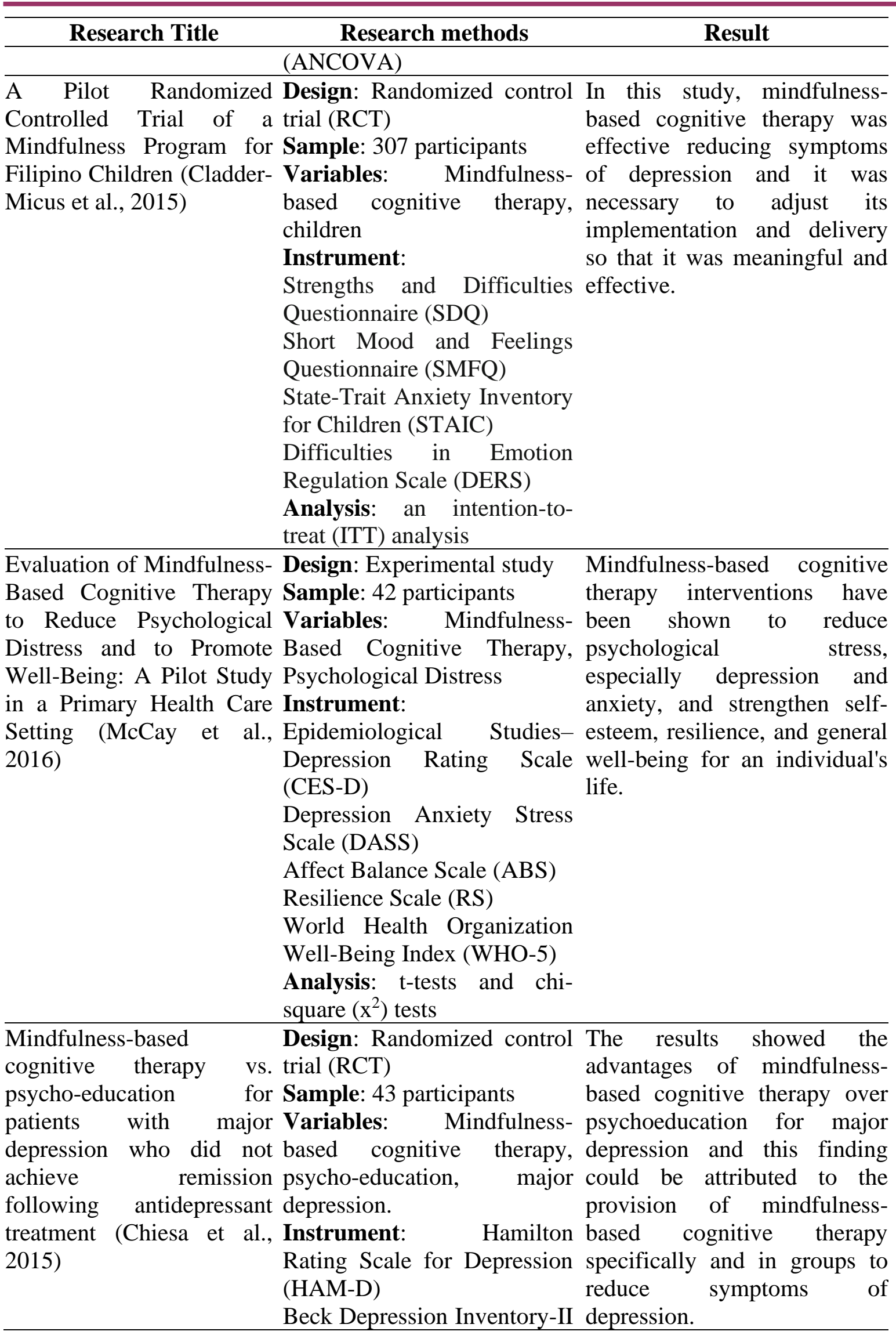




\section{STRADA Jurnal Ilmiah Kesehatan}

DOI: $10.30994 /$ sjik.v9i2.383

ISSN: 2252-3847 (print); 2614-350X (online)

Vol.9 No.2 November 2020 Page.761-771

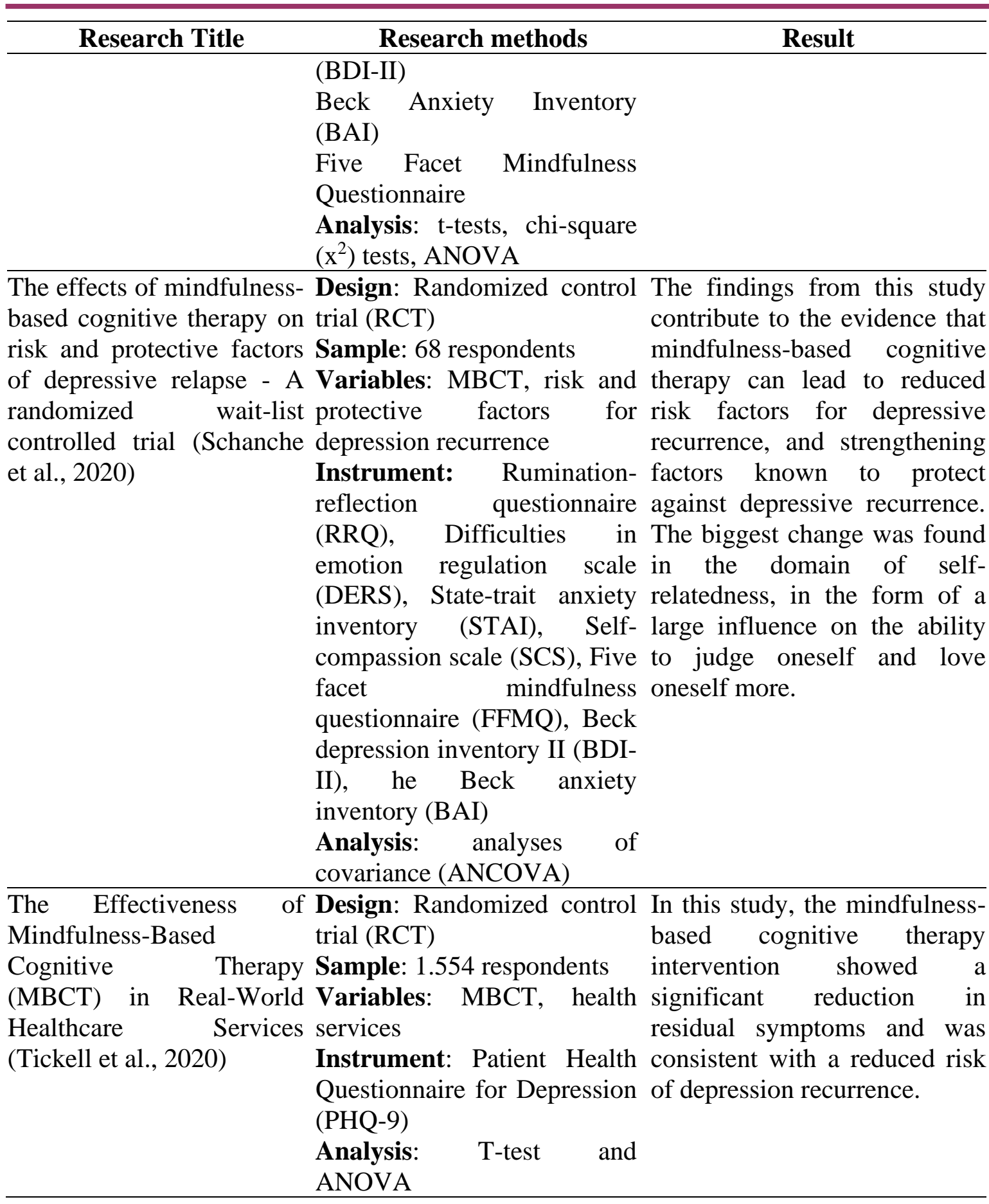

\section{DISCUSSION}

Depression is a common mental health condition and one of the most worrying phenomena that occur worldwide (Raj et al., 2019). Depression affects cognitive processes (Kircanski et al., 2012), emotional process (Visted et al., 2018), and self-attachment (MacBeth \& Gumley, 2012) by increasing the recurrence risk of depression. Individuals who were depressed increase susceptible to negative thinking or difficulty regulating emotions (Segal et al., 2006). Depressed individuals were reported to have higher levels of self-criticism and lower self-acceptance (Ehret et al., 2015). Several therapies have been 


\section{STRADA Jurnal Ilmiah Kesehatan}

DOI: $10.30994 /$ sjik.v9i2.383

ISSN: 2252-3847 (print); 2614-350X (online)

Vol.9 No.2 November 2020 Page.761-771

developed to strengthen a person's coping process, and one of the therapies is a cognitivebehavioral therapy approach that has provided evidence of effectiveness. Thus, research was consistently needed to improve emotional health and well-being, as well as encourage the use of adaptive coping skills to reduce the use of maladaptive coping skills (Raj et al., 2019).

Mindfulness is a complementary therapy that is described as current awareness of one's experiences, combined with acceptance and non-judgmental attitude (Bishop et al., 2004; Kabat-Zinn, J., 2013). Mindfulness can be understood as a specific form of meditation that seeks to improve psychological functioning through synergistic efforts between attention regulation, self-awareness, and emotional regulation, thereby increasing psychological resilience and self-regulation (Tang et al., 2015). In this review, the results suggested that MBCT contributes to lowering risk factors for depressive recurrence and strengthening factors that were known to protect depression recurrence. The biggest change was found in the domain of self-connection, in the form of a large influence on the ability to judge yourself and love yourself more. (Schanche et al., 2020).

Mindfulness-based cognitive therapy intervention also serves as an effective medium to improve the psychological function of depressed adolescents with suicidal thoughts (Raj et al., 2019). This study in line with the previous study showed that Mindfulness-based cognitive therapy can help weaken the link between depressive symptoms and suicidal thoughts and reduce susceptibility to depression and suicide (Barnhofer et al., 2015). Two previous studies found that mindfulness-based cognitive therapy interventions showed a significant reduction in residual symptoms, consistent with reducing the risk of depression recurrence, psychological distress especially depression and anxiety, and strengthened selfesteem, resilience, and general well-being for an individual's life (McCay et al., 2016; Tickell et al., 2020). Other studies have shown that mindfulness-based cognitive therapy both as a group and individually can improve psychological well-being, attention skills, and reduce symptoms of depression (Alampay et al., 2020; Schroevers et al., 2016). The studies that have been described in this review showed the strategies to reduce depressive symptoms can be done with mindfulness-based cognitive therapy interventions. Although several studies did nor showed significant values on all measured parameters, but most of the studies stated the positive effect of mindfulness-based cognitive therapy on symptoms of depression.

\section{CONCLUSION}

Mindfulness-based cognitive therapy intervention was a psychological intervention that makes a significant contribution to reducing symptoms of depression or anxiety. Nursing intervention should be facilitated by nurses or health workers who are familiar with the intervention and its management. It is necessary to research with a similar theme and modification of the variables as possible as recommended.

\section{REFERENCES}

Alampay, L. P., Galvez Tan, L. J. T., Tuliao, A. P., Baranek, P., Ofreneo, M. A., Lopez, G. D., Fernandez, K. G., Rockman, P., Villasanta, A., Angangco, T., Freedman, M. L., Cerswell, L., \& Guintu, V. (2020). A Pilot Randomized Controlled Trial of a Mindfulness Program for Filipino Children. Mindfulness, 11(2), 303-316. https://doi.org/10.1007/s12671-019-01124-8

Barnhofer, T., Crane, C., Brennan, K., Duggan, D. S., Crane, R. S., Eames, C., Radford, S., Silverton, S., Fennell, M. J. V., \& Williams, J. M. G. (2015). Mindfulness-Based 


\section{STRADA Jurnal Ilmiah Kesehatan}

DOI: $10.30994 /$ sjik.v9i2.383

ISSN: 2252-3847 (print); 2614-350X (online)

Vol.9 No.2 November 2020 Page.761-771

Cognitive Therapy (MBCT) Reduces the association between depressive symptoms and suicidal cognitions in patients with a history of suicidal depression. Journal of Consulting and Clinical Psychology, 83(6), 1013-1020. https://doi.org/10.1037/ccp0000027

Bishop, S. R., Lau, M., Shapiro, S., Carlson, L., Anderson, N. D., Carmody, J., Segal, Z. V., Abbey, S., Speca, M., Velting, D., \& Devins, G. (2004). Mindfulness: A proposed operational definition. Clinical Psychology: Science and Practice, 11(3), 230-241. https://doi.org/10.1093/clipsy/bph077

Chiesa, A., Castagner, V., Andrisano, C., Serretti, A., Mandelli, L., Porcelli, S., \& Giommi, F. (2015). Mindfulness-based cognitive therapy vs. psycho-education for patients with major depression who did not achieve remission following antidepressant treatment. Psychiatry Research, 226(2-3), 474-483. https://doi.org/10.1016/j.psychres.2015.02.003

Cladder-Micus, M. B., Vrijsen, J. N., Becker, E. S., Donders, R., Spijker, J., \& Speckens, A. E. M. (2015). A randomized controlled trial of Mindfulness-Based Cognitive Therapy (MBCT) versus treatment-as-usual (TAU) for chronic, treatment-resistant depression: Study protocol. BMC Psychiatry, 15(1), 1-8. https://doi.org/10.1186/s12888-015-0647-y

Ehret, A. M., Joormann, J., \& Berking, M. (2015). Examining risk and resilience factors for depression: The role of self-criticism and self-compassion. Cognition and Emotion, 29(8), 1496-1504. https://doi.org/10.1080/02699931.2014.992394

Fung, J., Kim, J. J., Jin, J., Chen, G., Bear, L., \& Lau, A. S. (2019). A Randomized Trial Evaluating School-Based Mindfulness Intervention for Ethnic Minority Youth: Exploring Mediators and Moderators of Intervention Effects. Journal of Abnormal Child Psychology, 47(1), 1-19. https://doi.org/10.1007/s10802-018-0425-7

Goldman, R. D., Rogovik, A. L., Lai, D., \& Vohra, S. (2008). Potential Interactions of Drug-Natural Health Products and Natural Health Products-Natural Health Products among Children. Journal of Pediatrics, 152(4). https://doi.org/10.1016/j.jpeds.2007.09.026

Howard, K. A. S., Ferrari, L., Nota, L., Solberg, V. S. H., \& Soresi, S. (2009). The relation of cultural context and social relationships to career development in middle school. Journal of Vocational Behavior, 75(2), 100-108. https://doi.org/10.1016/j.jvb.2009.06.013

Kabat-Zinn, J. (2013). Full catastrophe living: Using the wisdom of your body and mind to face stress, pain, and illness. Bantam Books.

Kircanski, K., Joormann, J., \& Gotlib, I. H. (2012). Cognitive aspects of depression. Wiley Interdisciplinary Reviews: Cognitive Science, 3(3), 301-313. https://doi.org/10.1002/wcs.1177

Krisnana, I., Rachmawati, P. D., Arief, Y. S., Kurnia, I. D., Nastiti, A. A., Safitri, I. F. N., \& Putri, A. T. K. (2019). Adolescent characteristics and parenting style as the determinant factors of bullying in Indonesia: A cross-sectional study. International Journal of Adolescent Medicine and Health, 1-9. https://doi.org/10.1515/ijamh-20190019

Ktut Dianovinina. (2018). Depresi pada Remaja: Gejala dan Permasalahannya. Jurnal Psikologi, 6(1), 69-78.

Liu, X. (2019). Effect of a Mindfulness-Based Intervention Program on Comprehensive Mental Health Problems of Chinese Undergraduates. Community Mental Health Journal, 55(7), 1179-1185. https://doi.org/10.1007/s10597-019-00426-4 


\section{STRADA Jurnal Ilmiah Kesehatan}

DOI: $10.30994 /$ sjik.v9i2.383

ISSN: 2252-3847 (print); 2614-350X (online)

Vol.9 No.2 November 2020 Page.761-771

MacBeth, A., \& Gumley, A. (2012). Exploring compassion: A meta-analysis of the association between self-compassion and psychopathology. Clinical Psychology Review, 32(6), 545-552. https://doi.org/10.1016/j.cpr.2012.06.003

McCay, E., Frankford, R., Beanlands, H., Sidani, S., Gucciardi, E., Blidner, R., Danaher, A., Carter, C., \& Aiello, A. (2016). Evaluation of Mindfulness-Based Cognitive Therapy to Reduce Psychological Distress and to Promote Well-Being: A Pilot Study in a Primary Health Care Setting. SAGE Open, 6(3). https://doi.org/10.1177/2158244016669547

Papalia \& Feldman. (2008). Human Development (Psikologi Perkembangan). Kencana.

Peltzer, K., \& Pengpid, S. (2018). High prevalence of depressive symptoms in a national sample of adults in Indonesia: Childhood adversity, sociodemographic factors and health risk behaviour. Asian Journal of Psychiatry, 33(December 2017), 52-59. https://doi.org/10.1016/j.ajp.2018.03.017

Potter \& Perry. (2005). Buku Ajar Fundamental Keperawatan. EGC.

Pratt, L.A., \& Brody, D.J. (2014). Depression in the U.S. Household Population, 20092012.

Raj, S., Sachdeva, S. A., Jha, R., Sharad, S., Singh, T., Arya, Y. K., \& Verma, S. K. (2019). Effectiveness of mindfulness based cognitive behavior therapy on life satisfaction, and life orientation of adolescents with depression and suicidal ideation. Asian Journal of Psychiatry, 39, 58-62. https://doi.org/10.1016/j.ajp.2018.12.001

Santrock, J.W. (2007). Remaja. Erlangga.

Schanche, E., Vøllestad, J., Vøllestad, J., Visted, E., Visted, E., Svendsen, J. L., Svendsen, J. L., Osnes, B., Osnes, B., Binder, P. E., Franer, P., \& Sørensen, L. (2020). The effects of mindfulness-based cognitive therapy on risk and protective factors of depressive relapse - A randomized wait-list controlled trial. BMC Psychology, 8(1), 1-16. https://doi.org/10.1186/s40359-020-00417-1

Schroevers, M. J., Tovote, K. A., Snippe, E., \& Fleer, J. (2016). Group and Individual Mindfulness-Based Cognitive Therapy (MBCT) Are Both Effective: a Pilot Randomized Controlled Trial in Depressed People with a Somatic Disease. Mindfulness, 7(6), 1339-1346. https://doi.org/10.1007/s12671-016-0575-Z

Segal, Z. V., Kennedy, S., Gemar, M., Hood, K., Pedersen, R., \& Buis, T. (2006). Cognitive reactivity to sad mood provocation and the prediction of depressive relapse. Archives of General Psychiatry, 63(7), 749-755. https://doi.org/10.1001/archpsyc.63.7.749

Stuart, G. W. (2016). Prinsip dan Praktik Keperawatan Kesehatan Jiwa Stuart (Buku 2). Elsevier Ltd.

Tang, Y. Y., Hölzel, B. K., \& Posner, M. I. (2015). The neuroscience of mindfulness meditation. Nature Reviews Neuroscience, 16(4), 213-225. https://doi.org/10.1038/nrn3916

Tickell, A., Ball, S., Bernard, P., Kuyken, W., Marx, R., Pack, S., Strauss, C., Sweeney, T., \& Crane, C. (2020). The Effectiveness of Mindfulness-Based Cognitive Therapy (MBCT) in Real-World Healthcare Services. Mindfulness, 11(2), 279-290. https://doi.org/10.1007/s12671-018-1087-9

United Nations Children's Fund (UNICEF). (2011). The state of the world's children 2011: Adolescence an age opportunity. Hatteras Press.

Visted, E., Vøllestad, J., Nielsen, M. B., \& Schanche, E. (2018). Emotion regulation in current and remitted depression: A systematic review and meta-analysis. Frontiers in Psychology, 9(MAY). https://doi.org/10.3389/fpsyg.2018.00756 


\section{STRADA Jurnal Ilmiah Kesehatan}

DOI: $10.30994 /$ sjik.v9i2.383

ISSN: 2252-3847 (print); 2614-350X (online)

Vol.9 No.2 November 2020 Page.761-771

Vos, T., Abajobir, A. A., Abbafati, C., Abbas, K. M., Abate, K. H., Abd-Allah, F., Abdulle, A. M., Abebo, T. A., Abera, S. F., Aboyans, V., Abu-Raddad, L. J., Ackerman, I. N., Adamu, A. A., Adetokunboh, O., Afarideh, M., Afshin, A., Agarwal, S. K., Aggarwal, R., Agrawal, A., ... Murray, C. J. L. (2017). Global, regional, and national incidence, prevalence, and years lived with disability for 328 diseases and injuries for 195 countries, 1990-2016: A systematic analysis for the Global Burden of Disease Study 2016. The Lancet, 390(10100), 1211-1259. https://doi.org/10.1016/S0140-6736(17)32154-2

Weare, K., \& Nind, M. (2011). Mental health promotion and problem prevention in schools: What does the evidence say? Health Promotion International, 26(SUPPL. 1). https://doi.org/10.1093/heapro/dar075

WHO. (2017). Depression and other common mental disorders: global health estimates. World Health Organization, 1-24. https://doi.org/CC BY-NC-SA 3.0 IGO 